\title{
Supplemental Foliar Potassium Applications during Muskmelon Fruit Development Can Improve Fruit Quality, Ascorbic Acid, and Beta-carotene Contents
}

\author{
Gene E. Lester ${ }^{1}$ \\ U.S.Department of Agriculture, Agricultural Research Service, Kika de la Garza Subtropical Agricultural \\ Research Center, 2413 East Highway 83, Building 200, Weslaco, TX 78596 \\ John L. Jifon \\ Texas A\&M University, TAES, 2415 East Highway 83, Weslaco, TX 78596 \\ Gordon Rogers \\ Faculty of Agriculture, Food and Natural Resources, University of Sydney, NSW, 2006, Australia
}

\begin{abstract}
AdDitional INDEX WORDS. cantaloupe, color, Cucumis melo, firmness, maturity, soluble solids, sugars
Abstract. Muskmelon [Cucumis melo L. (Reticulatus Group)] fruit sugar content is directly related to potassium (K)mediated phloem transport of sucrose into the fruit. However, during fruit growth and maturation, soil fertilization alone is often inadequate (due to poor root uptake and competitive uptake inhibition from calcium and magnesium) to satisfy the numerous K-dependent processes, such as photosynthesis, phloem transport, and fruit growth. Experiments were conducted during Spring 2003 and 2004 to determine if supplemental foliar $\mathrm{K}$ applications during the fruit growth and maturation period would alleviate this apparent inadequate $\mathrm{K}$ availability in orange-flesh muskmelon ' $\mathrm{Cruiser}$ '. Plants were grown in a greenhouse and fertilized throughout the study with a soil-applied N-P-K fertilizer. Flowers were hand pollinated and only one fruit per plant was allowed to develop. Starting at 3 to 5 days after fruit set, and up to 3 to 5 days prior to fruit maturity (full slip), entire plants, including the fruit, were sprayed with a glycine amino acid-complexed potassium (potassium metalosate, $24 \% \mathrm{~K}$ ) solution, diluted to $4.0 \mathrm{~mL} \cdot \mathrm{L}^{-1}$. Three sets of plants were sprayed either weekly (once per week), biweekly (once every 2 weeks) or not sprayed (control). Fruit from plants receiving supplemental foliar $\mathrm{K}$ matured on average 2 days earlier than those from control plants. In general, there were no differences in fruit maturity or quality aspects between the weekly and biweekly treatments except for fruit sugar and beta-carotene concentrations, which were significantly higher in the weekly compared to the biweekly or control treatments. Supplemental foliar $\mathbf{K}$ applications also resulted in significantly firmer fruit with higher $\mathbf{K}$, soluble solids, total sugars, ascorbic acid (vitamin $\mathrm{C}$ ) and beta-carotene concentrations than fruit from control plants. These results demonstrate that carefully timed foliar $\mathrm{K}$ nutrition can alleviate the developmentally induced $\mathrm{K}$ deficiency effects on fruit quality and marketability.
\end{abstract}

Potassium is the second most abundant macro-nutrient element after nitrogen in terms of amounts found in plant tissues except seeds (Bidwell, 1974; Marschner, 1995). Optimum K concentrations in plant tissue usually range from $2 \%$ to $5 \%$ of plant dry weight. Even though $\mathrm{K}$ is not an integral part of any major plant structures, it plays a key regulatory role in many physiological processes vital to plant growth (Wyn Jones et al., 1979). As a major inorganic osmolyte, the role of $\mathrm{K}$ in cell osmoregulation and turgor maintenance is crucial in processes such as stomatal opening/closing, cell expansion, tropisms, and leaf movements. Due to its high concentration in the cytoplasm (100 to $200 \mathrm{~mm}$ ) and chloroplasts (100 to $200 \mathrm{~mm}$ ) it stabilizes the $\mathrm{pH}$ between 7 and 8 in these organelles and optimizes enzyme activities (Marschner, 1995). As an activator of many enzymes, $K$ plays a vital role in photosynthesis, protein synthesis, and oxidative metabolism. In addition to affecting photosynthesis through stomatal regula-

Received for publication 1 Dec. 2004. Accepted for publication 29 Jan. 2005. This research was funded by the USDA-ARS under CRIS No. 6204-43000-014-00D to G.E.L. Technical assistance of R. Meyer (USDA-ARS, Weslaco, Texas) and Y. Luna (TAES, Weslaco, Texas) is gratefully acknowledged. Use of company or product names by the USDA and TAES does not imply approval or recommendation of the product to the exclusion of others that may be suitable.

TTo whom reprint requests should be addressed: Email: glester@weslaco.ars. usda.gov;phone: (956) 447-6322; fax: (956) 447-6323. tion, $\mathrm{K}$ is also involved as the major counterion in the establishment of a transmembrane $\mathrm{pH}$ gradient during synthesis of ATP (photophosphorylation) in the thylakoid membranes (Tester and Blatt, 1989). In K-deficient plants, processes dependent on ATP for metabolic energy, such as photosynthesis, are slowed down and plant respiration increases, thus reducing the rate of growth and development (Peoples and Koch, 1979; Pettigrew, 1999; Terry and Ulrich, 1973). Phloem loading, transport rate, and unloading of sucrose are key processes for crop yield and plant productivity that are also enhanced by optimum levels of plant $\mathrm{K}$ (Doman and Geiger, 1979; Peel and Rogers, 1982). It is however, unclear whether the K stimulation of sucrose loading/unloading is a direct effect on the loading mechanism (i.e., maintenance of the transmembrane $\mathrm{pH}$ gradient) or an indirect one via enhanced sucrose synthesis.

Almost all $\mathrm{K}$ found in plant tissues is taken up by roots from the soil solution in its ionic form $\left(\mathrm{K}^{+}\right)$. Soil $\mathrm{K}$ supply and plant uptake are regulated by plant and environmental factors (Mengel and Kirkby, 1980). For instance, in many species, young plants with actively growing roots are more efficient in obtaining $\mathrm{K}$ than mature plants. Soil $\mathrm{K}$ is also more readily available for root uptake in well-aerated, neutral-to-acid soils with high cation exchange capacity compared to hypoxic, high $\mathrm{pH}$ soils. Considerable metabolic energy is required for $\mathrm{K}$ uptake, and in many species, uptake occurs mainly during the vegetative stages of 
plant growth when root growth is not limited by carbohydrate supply (Fisher et al., 1970). During reproductive development, competition for photoassimilates between developing fruits and vegetative organs may limit root growth and nutrient uptake, including $\mathrm{K}$ (Ho, 1988). This creates an apparent K deficiency that can slow down translocation of photoassimilates to developing seeds and fruits, potentially reducing yield and quality. Lin et al. (2004) found that increasing the K supply from 120 to 240 $\mathrm{mg} \cdot \mathrm{L}^{-1}$ in a hydroponics system resulted in higher muskmelon fruit sugar concentrations. For field-grown plants, increasing soil fertilizer inputs may not be enough to alleviate the developmentally induced $\mathrm{K}$ deficiency partly because of reduced root growth during reproductive development and also because of competition for binding sites on roots from cations such as $\mathrm{NH}_{4}{ }^{+}$(Clarkson, 1989; Engels and Marschner, 1993). Inadequate soil K supply also reduces translocation of amino acids and minerals such as magnesium and calcium which are essential for melon fruit quality and postharvest shelf-life (Lester and Grusak, 1999). Therefore, soil-derived $\mathrm{K}$, which is essential for sugar transport and unloading into fruit during fruit growth and development is not always optimal during the critical fruit development period.

The objective of this study was to determine if supplemental foliar $\mathrm{K}$ applications during the fruit growth and maturation period would alleviate this apparent inadequate $\mathrm{K}$ availability in orange-flesh muskmelon 'Cruiser'. In particular, the effects of supplementing regular soil $\mathrm{K}$ fertilization with foliar $\mathrm{K}$ applications on fruit earliness, size, weight, firmness, fruit sugars, and human wellness compounds such as ascorbic acid, beta-carotene, and $\mathrm{K}$ concentrations were studied.

\section{Materials and Methods}

Plant material and greenhouse conditions. During the end of Jan. 2003 and 2004, seeds of netted, orange-flesh muskmelon 'Cruiser' were planted in 15-L black plastic pots containing a commercial potting medium (Sunshine mix \#2; Sun Gro Horticulture, Bellevue, Wash.) in a greenhouse at the U.S. Dept. of Agriculture, Agricultural Research Service, Kika de la Garza Subtropical Agricultural Research Center, Weslaco, Tex. (lat. $26^{\circ} 10^{\prime} \mathrm{N}$, long. $97^{\circ} 58^{\prime} \mathrm{W}$, elevation $21 \mathrm{~m}$ ). Following germination [7 $\mathrm{d}$ after planting (DAP)], seedlings were thinned to one per pot. Plants were watered at least once per day using an automatic drip irrigation system, and fertigated two times per week with a complete water-soluble fertilizer $(10 \mathrm{~N}-4.4 \mathrm{P}-8.3 \mathrm{~K}$; Peter's Corp., St. Louis) during vegetative and fruit developmental stages. During flowering/pollination, plants were fertilized two times per week with a $4.5 \mathrm{~N}-9.9 \mathrm{P}-6.3 \mathrm{~K}$ nutrient solution. A $12-\mathrm{h}$ photoperiod was maintained throughout each experiment using a combination of natural daylight in the glasshouse and 400-W high-pressure sodium-vapor lamps $\left(300 \mu \mathrm{mol} \cdot \mathrm{m}^{-2} \cdot \mathrm{s}^{-1}\right)$. The average daily photosynthetic photon flux $(P P F)$ at the canopy level was $15 \pm 3.8 \mathrm{~mol} \cdot \mathrm{m}^{-2}$ in 2003 and $21.1 \pm 0.8 \mathrm{~mol} \cdot \mathrm{m}^{-2}$ in 2004 . Cumulative $P P F$ for the entire growth period was $1156 \mathrm{~mol} \cdot \mathrm{m}^{-2}$ and $1768 \mathrm{~mol} \cdot \mathrm{m}^{-2}$ for 2003 and 2004 , respectively. Average day/ night temperatures were $28.8 \pm 4.4^{\circ} \mathrm{C} / 21.7 \pm 3.2^{\circ} \mathrm{C}$ and average day/night relative humidities were $48 \% \pm 11 \% / 68 \% \pm 11 \%$ each year. Flowers were hand-pollinated and only one fruit per plant was allowed to develop.

Treatments. Immediately after fruit set $(\approx 3$ to $5 \mathrm{~d})$, and up to $3 \mathrm{~d}$ prior to fruit maturation (full-slip), entire plants including developing fruit were sprayed to runoff with a glycine amino acid-complexed $\mathrm{K}$ solution (potassium metalosate, 24\% K; Al- bion Advanced Nutrition, Clearfield, Utah) diluted to $4.0 \mathrm{~mL} \cdot \mathrm{L}^{-1}$ $(0.096 \% \mathrm{~K})$. This non-salt form of $\mathrm{K}$ was selected because of its effectiveness in penetrating melon fruit cuticles (Lester and Grusak, 1999) and also because it has little or no phytotoxicity problems compared to other sources of $\mathrm{K}^{+}$such as $\mathrm{KCl}, \mathrm{KNO}_{3}$, and $\mathrm{K}_{2} \mathrm{SO}_{4}$ (Swietlik and Faust, 1984; Tao et al., 1990). Treatments were applied to three sets of plants: one set of plants was sprayed weekly (once per week, for a total of four to five sprays), a second set was sprayed biweekly (once every 2 weeks for a total of two to three sprays), and the third was not sprayed (control). Plants were randomly distributed throughout the glasshouse with adequate spacing $(\geq 45 \mathrm{~cm})$ between pots to minimize mutual shading. All treatments were applied at 0800 HR on each spray event. Fruits were inspected daily and were harvested as they reached maturity (full-slip). Matured fruit were harvest at $0800 \mathrm{HR}$ each day. At harvest, the duration from anthesis to full slip was recorded for each fruit together with fruit size and fresh weight. After harvest, each fruit (10 replicates per treatment) was stored at $21^{\circ} \mathrm{C}$ for $3 \mathrm{~d}$ (to simulate commercial retail display conditions) prior to internal fruit quality analyses.

Tissue analyses. Following $21{ }^{\circ} \mathrm{C}$ storage, fruit firmness (expressed as Newtons) was measured with a V-tip probe $(1 \mathrm{~cm}$ long $\times 5.8 \mathrm{~mm}$ diameter $\times 1 \mathrm{~mm}$ wide) attached to a force gauge (Mark-10, model MG20; Wagner Instr. Co., Greenwich, Conn.)]. External fruit firmness measurements (2004 only) were made at the equatorial region of each fruit; the epidermal tissue was removed using a potato peeler before measurements. Internal firmness measurements (2004 only) were determined on middle-mesocarp tissue from one-half of an equatorially cut fruit.

A chromameter (CR-200; Minolta Corp., Ramsey, N.J.), calibrated using a clean white ceramic plate (standard for white), was used to quantify fruit mesocarp tissue color characteristics. Color measurements were made at three locations around the cross section of each fruit cut at the equatorial plane and expressed in the $\mathrm{L}^{*}, \mathrm{C}^{*}$, and ho mode where $\mathrm{L}^{*}=$ lightness $($ black $=0$, white $=$ $100) ; \mathrm{C}^{*}=$ chroma or color intensity (degree of departure from gray toward pure chromatic color $)$; and $\mathrm{h}^{\circ}=$ hue angle $\left(0^{\circ}=\mathrm{red}\right.$, $90^{\circ}=$ yellow, $180^{\circ}=$ bluish green, $270^{\circ}=$ blue $)$. Measurements from the three locations were averaged for each fruit.

At the time of fruit harvest, leaf, stem, and petiole samples were collected, washed with distilled water, dried at $70^{\circ} \mathrm{C}$ for 48 $\mathrm{h}$, and weighed. Tissue $\mathrm{K}$ concentrations in leaf, stem, petiole, and fruit (epidermis and mesocarp) tissues were determined on finely ground, ashed $\left(500{ }^{\circ} \mathrm{C}\right.$ for $\left.5 \mathrm{~h}\right)$ tissue using atomic absorption spectroscopy.

Fruit tissue, sampled from the edible equatorial middle-mesocarp region of each fruit, was used for dry weight, $\mathrm{K}$, soluble solids, sucrose, glucose, fructose, ascorbic acid, and beta-carotene analyses as described below. Juice samples were expressed from fresh fruit tissue with a hand-held garlic press and analyzed for soluble solids concentration using a temperature-corrected digital refractometer (Reichert Scientific Instruments, Buffalo, N.Y.). Fruit sugars were extracted from $0.3 \mathrm{~g}$ lyophilized tissue by stirring in $5 \mathrm{~mL}$ of $90^{\circ} \mathrm{C}, 80 \%$ ethanol for $2 \mathrm{~min}$. The solution was filtered (Whatman, No. 1; Maidstone, U.K.) and the residue washed with additional $5 \mathrm{~mL}$ of $80 \%$ ethanol $\left(90{ }^{\circ} \mathrm{C}\right)$. One milliliter of the extract was filtered through a pre-wetted (80\% ethanol) C18 Sep-Pak (Waters Corp., Milford, Mass.) before determination of fructose, glucose, and sucrose using the high-performance liquid chromatography (HPLC) procedure previously described by Lester and Dunlap (1985). Middle-mesocarp tissue dry weights were determined as a percent of fresh tissue after lyophilization. 
Free ascorbic acid and dehydroascorbic acid were extracted from of frozen/homogenized middle-mesocarp tissue $(\approx 7.5 \mathrm{~g})$ with ice-cold $5 \%(\mathrm{w} / \mathrm{v})$ meta-phosphoric acid $(15 \mathrm{~mL})$. Homogenized tissue was centrifuged at $7000 g_{n}$ for $15 \mathrm{~min}$ at $4{ }^{\circ} \mathrm{C}$. Detection of free ascorbic acid and dehydroascrobic acid was at $525 \mathrm{~nm}$ according to Hodges et al. (2001) and concentrations were calculated using a standard curve developed earlier.

Beta-carotene was extracted under low light conditions from lyophilized mesocarp tissue $(0.020 \mathrm{~g})$ using ice-cold heptane $(1.0 \mathrm{~mL}))$ plus $0.5 \mathrm{~mL}$ internal standard [trans Apo- $8^{\prime}$-carotene $\left(40 \mu \mathrm{g} \cdot \mathrm{mL}^{-1}\right)$ (Sigma Chemical Co., St. Louis)] according to the modified procedure of Koch and Goldman (2005). The internal standard stock solution was made by dissolving Apo- 8 '-carotene in $1.0 \mathrm{~mL}$ methanol then bringing to volume $(250 \mathrm{~mL})$ with heptane before storage in the dark at $-20^{\circ} \mathrm{C}$. The fruit tissue cocktail was vortexed for $2 \mathrm{~min}$, then centrifuged at $3000 \mathrm{~g}_{\mathrm{n}}$ for $10 \mathrm{~min}$ at $0^{\circ} \mathrm{C}$. One milliliter of the supernatant was removed and $1.5 \mathrm{~mL}$ fresh ice-cold heptane was added to the pellet, vortexed for 2 min then centrifuged as above. A second $1.0 \mathrm{~mL}$ of the supernatant was removed and $1.0 \mathrm{~mL}$ fresh ice-cold heptane was added to the pellet, vortexed for $2 \mathrm{~min}$ then centrifuged as above. A third $1.0 \mathrm{~mL}$ of the supernatant was removed; the supernatants were pooled and a 1.0-mL aliquot was passed through a 0.2-mm nylon Millex-LCR 13 filter (Millipore Corp., Bedford, Mass.) and stored in the dark at $-20{ }^{\circ} \mathrm{C}$ until HPLC determination. Twenty microliters of each extract was injected into an HPLC system (Agilent Technologies, New Castle, Del.) equipped with a Discovery C18, $5 \mu \mathrm{m}$ column $(15 \mathrm{~cm} \times 4.6 \mathrm{~mm})$ and a guard column $[2 \mathrm{~cm} \times 4.0 \mathrm{~mm}$ (Supelco, Bellefonte, $\mathrm{Pa}$.)]. Beta-carotene was separated in a mobile phase of methanol at a flow rate of $2.0 \mathrm{~mL} \cdot \mathrm{min}^{-1}$ and detected at $454 \mathrm{~nm}$.

Statistical anAlysis. Analysis of variance (ANOVA) using the general linear model procedures of SAS (SAS Inst., Cary, N.C.) was conducted as a split-plot design with year as main plot, and K treatments as sub-plots. Duncan's multiple range tests $(P \leq 0.05)$ were performed to further evaluate the magnitude of differences between treatment means. Data are the average of ten single-fruit replications per K treatment.

\section{Results}

Fruit on plants receiving supplemental foliar K applications reached harvestable maturity on average, two days earlier than control fruit $[P \leq 0.05$ (Table 1) $]$. Individual fruit fresh weight and the percent dry weight of K-treated fruit did not differ significantly from that of control fruit. External (hypodermal-mesocarp, under the peel) and internal (edible middle-mesocarp) tissues were significantly firmer than those of control fruit (Table 1).

Plants receiving supplemental foliar $\mathrm{K}$ treatments generally had higher $\mathrm{K}$ concentrations in leaf, petiole, and stem tissues compared to control plants, but this was only significant for petioles in both years and stems in 2004 (Table 2). There were generally no significant differences in tissue $\mathrm{K}$ concentrations between weekly and biweekly treatments except for stem tissues in 2004 where plants sprayed on a weekly basis had a significantly higher $\mathrm{K}$ concentration than those sprayed on a biweekly basis. Plants receiving supplemental foliar $\mathrm{K}$ applications also had higher $\mathrm{K}$ concentrations in the fruit hypodermal- and middle-mesocarp tissues but not in the epidermal tissues (Table 3).
In both years, fruit on plants receiving supplemental foliar $\mathrm{K}$ applications were more intensely orange-colored than those from control plants as indicated by the higher hue angle values of control, compared to treated fruit (Table 4). The intense orange color of K-treated fruits was also accompanied by significantly higher soluble solids, ascorbic acid and beta-carotene contents compared to control fruit (Table 4). Fruit beta-carotene concentrations were also significantly higher in weekly foliar K-treated fruit compared to the biweekly treated and control fruit.

In both years, fruit fructose, glucose, sucrose, and total sugar concentrations were generally higher in fruits receiving weekly foliar $\mathrm{K}$ applications than in biweekly $\mathrm{K}$ or control treatments (Table 5). In 2003, however, glucose and sucrose concentrations of K-treated fruits were not significantly different from those of control fruits. Fructose and total sugars were significantly higher in foliar K-treated fruit compared to control fruit in both 2003 and 2004.

\section{Discussion}

Even though all plants in all the treatments received sufficient $\mathrm{K}$ in soil applied fertilizer, supplemental foliar $\mathrm{K}$ treatments resulted in higher $\mathrm{K}$ accumulation in edible fruit mesocarp [9\% (average for both years)] and leaf tissues [32\% (average for both years)] compared to control nonsprayed plants. This suggests that tissue $\mathrm{K}$ concentrations of plants grown in apparently $\mathrm{K}$-sufficient rooting media can be improved by foliar K sprays during the fruit development and maturation period. This result also indicates that even though soil-supplied K was nonlimiting, plant uptake was not sufficient for maximum nontoxic tissue $\mathrm{K}$ accumulation. Supplemental foliar K applications also resulted in earlier maturity of treated fruit compared to controls. While the mechanisms for this effect are unclear, similar K-induced effects on fruit $\mathrm{K}$ and firmness have also been reported in tomatoes (Lycopersicon esculentum Mill.)(Chapagain and Wiesman, 2004). Earlier maturity is a desirable economic trait for muskmelon production in regions where adequate solar radiation flux can permit sufficient soluble solids accumulation in fruits before full-slip. Increased firmness of K-treated compared to control fruit (Table 1) maybe an indirect consequence of enhanced phloem transport of calcium to fruits perhaps due to increased osmotic potential in fruit cells due to higher $\mathrm{K}^{+}$. Postharvest Ca-treatment has been shown to enhance fruit firmness and the shelf life of muskmelon fruit (Lester and Grusak, 1999).

Increased fruit $\mathrm{K}$ contents resulting from the supplemental foliar application was accompanied by increased fruit sugar levels. Photosynthesis rates are reported to increase with increased leaf $\mathrm{K}$ concentrations and this could be one mechanism of increased

Table 1. Influence of foliar applications of amino-acid-chelated potassium as a supplement to soil fertilization on muskmelon ('Cruiser') fruit maturation (abscission), fruit weight, and external and internal firmness. Entire plants and fruit were sprayed weekly, biweekly, or not sprayed (control) between anthesis (pollination) and fruit abscission (harvest). Shown are data from glasshouse experiments during Spring 2003 and 2004.

\begin{tabular}{|c|c|c|c|c|c|c|c|c|}
\hline \multirow[b]{3}{*}{ Treatment } & \multirow{2}{*}{\multicolumn{2}{|c|}{$\begin{array}{c}\text { Maturity } \\
\text { (d to harvest) }\end{array}$}} & \multirow{2}{*}{\multicolumn{2}{|c|}{$\begin{array}{c}\text { Fruit wt } \\
(\mathrm{kg})\end{array}$}} & \multirow{2}{*}{\multicolumn{2}{|c|}{$\begin{array}{l}\text { Dry wt } \\
(\%)\end{array}$}} & \multicolumn{2}{|c|}{$(\mathrm{N})$} \\
\hline & & & & & & & External & Internal \\
\hline & 2003 & 2004 & 2003 & 2004 & 2003 & 2004 & 2004 & 2004 \\
\hline Control & $37 a^{z}$ & $35 \mathrm{a}$ & $2.4 \mathrm{a}$ & $2.3 \mathrm{a}$ & $9.2 \mathrm{a}$ & $9.0 \mathrm{a}$ & $13.5 \mathrm{~b}$ & $6.6 \mathrm{~b}$ \\
\hline Biweekly & $35 \mathrm{~b}$ & $33 \mathrm{~b}$ & $2.1 \mathrm{a}$ & $2.0 \mathrm{a}$ & $8.9 \mathrm{a}$ & $8.6 \mathrm{a}$ & $15.3 \mathrm{ab}$ & $8.4 \mathrm{a}$ \\
\hline Weekly & $35 \mathrm{~b}$ & $33 \mathrm{~b}$ & $2.1 \mathrm{a}$ & $2.2 \mathrm{a}$ & $8.7 \mathrm{a}$ & $8.7 \mathrm{a}$ & $18.0 \mathrm{a}$ & $8.5 \mathrm{a}$ \\
\hline
\end{tabular}

${ }^{2}$ Means with the same letter, within a column, are not significant using Duncan's multiple range test at the $95 \%$ probability level $(n=10)$. 
Table 2. The effects of foliar applications of amino-acid-chelated potassium (K) as a supplement to soil fertilization on muskmelon ('Cruiser') tissue K concentrations. Entire plants and fruit were sprayed weekly, biweekly, or not sprayed (control) between anthesis (pollination) and fruit abscission (full-slip). Shown are data from glasshouse experiments during Spring 2003 and 2004.

\begin{tabular}{|c|c|c|c|c|c|c|}
\hline \multirow[b]{2}{*}{ Treatment } & \multicolumn{2}{|c|}{$\begin{array}{c}\text { Leaf K } \\
\left(\mathrm{mg} \cdot \mathrm{g}^{-1} \text { dry wt) }\right.\end{array}$} & \multicolumn{2}{|c|}{$\begin{array}{c}\text { Petiole K } \\
\left(\mathrm{mg} \cdot \mathrm{g}^{-1} \text { dry wt) }\right.\end{array}$} & \multicolumn{2}{|c|}{$\begin{array}{c}\text { Stem K } \\
\left(\mathrm{mg} \cdot \mathrm{g}^{-1} \text { dry wt }\right)\end{array}$} \\
\hline & 2003 & 2004 & 2003 & 2004 & 2003 & 2004 \\
\hline Control & $12.6 \mathrm{a}^{\mathrm{z}}$ & $21.3 \mathrm{a}$ & $59.5 \mathrm{~b}$ & $56.1 \mathrm{~b}$ & $40.6 \mathrm{a}$ & $34.0 \mathrm{c}$ \\
\hline Biweekly & $15.7 \mathrm{a}$ & $21.9 \mathrm{a}$ & $81.7 \mathrm{a}$ & $84.9 \mathrm{a}$ & $39.3 \mathrm{a}$ & $39.1 \mathrm{~b}$ \\
\hline Weekly & $14.1 \mathrm{a}$ & $20.2 \mathrm{a}$ & $82.5 \mathrm{a}$ & $86.8 \mathrm{a}$ & $44.5 \mathrm{a}$ & $43.1 \mathrm{a}$ \\
\hline
\end{tabular}

${ }^{2}$ Means with the same letter, within a column, are not significant using Duncan's multiple range test at the $95 \%$ probability level $(n=10)$.

Table 3. Influence of foliar applications of amino-acid-chelated potassium (K) as a supplement to soil fertilization on muskmelon ('Cruiser') fruit tissue K concentrations. Entire plants and fruit were sprayed weekly, biweekly, or not sprayed (control) between anthesis (pollination) and fruit abscission (full-slip). Shown are data from glasshouse experiments during Spring 2003 and 2004.

\begin{tabular}{|c|c|c|c|c|c|c|}
\hline \multirow[b]{2}{*}{ Treatment } & \multicolumn{2}{|c|}{$\begin{array}{c}\text { Epidermis K } \\
\left(\mathrm{mg} \cdot \mathrm{g}^{-1} \text { dry wt) }\right.\end{array}$} & \multicolumn{2}{|c|}{$\begin{array}{c}\text { Hypodermal- } \\
\text { mesocarp K } \\
\left(\mathrm{mg} \cdot \mathrm{g}^{-1} \text { dry wt) }\right.\end{array}$} & \multicolumn{2}{|c|}{$\begin{array}{c}\text { Middle- } \\
\text { mesocarp K } \\
\left(\mathrm{mg} \cdot \mathrm{g}^{-1} \text { dry wt) }\right.\end{array}$} \\
\hline & 2003 & 2004 & 2003 & 2004 & 2003 & 2004 \\
\hline Control & $20.8 \mathrm{a}^{\mathrm{z}}$ & $19.6 \mathrm{a}$ & $28.2 \mathrm{~b}$ & $28.8 \mathrm{~b}$ & $24.2 \mathrm{~b}$ & $24.8 \mathrm{~b}$ \\
\hline Biweekly & $22.1 \mathrm{a}$ & $19.2 \mathrm{a}$ & $33.2 \mathrm{a}$ & $31.8 \mathrm{a}$ & $26.5 \mathrm{ab}$ & $25.6 \mathrm{ab}$ \\
\hline Weekly & $22.9 \mathrm{a}$ & $20.6 \mathrm{a}$ & $32.2 \mathrm{a}$ & $33.1 \mathrm{a}$ & $27.7 \mathrm{a}$ & $26.1 \mathrm{a}$ \\
\hline
\end{tabular}

zMeans with the same letter, within a column, are not significant using Duncan's multiple range test at the $95 \%$ probability level $(n=10)$.

sugar contents in fruit (Peoples and Koch, 1979; Pettigrew, 1999; Terry and Ulrich, 1973). However, photosynthesis rates measured during the fruit maturation period were similar among control and K-treated fruits (data not shown). Increased phloem loading, transport rate and/or unloading of sugars could also account for the increased fruit sugar levels, although it is uncertain whether this is a direct effect (of enhanced phloem unloading in fruits) or an indirect effect (e.g., enhanced sucrose synthesis in source leaves) (Doman and Geiger, 1979; Peel and Rogers, 1982). Potassium-induced increases in fruit sugar levels have also been reported in hydroponically grown muskmelon plants (Lin et al., 2004), however, the mechanism for this effect was also unclear. Although a threshold tissue K concentration for attaining optimum fruit sugar levels has not been established, our melon data provide additional evidence that fruit sugar concentrations can be increased through supplemental foliar K sprays.

There was a strong positive correlation between fruit $\mathrm{K}$ concentration and fruit sugar contents $[r=0.90,(P<0.001)]$. In particular, the ratio of fruit fructose to fruit sucrose content was significantly increased by supplemental foliar K sprays in both years. This suggests that acid invertase (EC 3.2.1.26) activity may be retained longer in fruit with higher $\mathrm{K}$ concentration than in low-K fruit (Lester et al., 2001). High fructose content in melons is a desirable fruit characteristic since fructose is perceived to be sweeter than sucrose or glucose (Shallenberger, 1980).

Both ascorbic acid, derived from glucose (Hopkins, 1963) and beta-carotene, derived from chloroplasts (Gross, 1991) were higher in K-treated fruit than in control fruit (Table 4). In addition to its many biochemical functions, $\mathrm{K}$ seems to improve plant tolerance of various environmental stresses such as drought, low temperature or salinity all of which trigger cellular oxidative stress (Hodges et al., 2001). A plausible mechanism for the $\mathrm{K}$-induced stress tolerance is through increased antioxidant activity of ascorbic acid. Ascorbic acid can act as an antioxidant by donating electrons and hydrogen ions, and reacting with reactive oxygen species or free radicals. Similarly, beta-carotene is an accessory pigment involved in radiation capture and in protecting chlorophyll molecules from photo-oxidation in excessive light. It is unclear how high $\mathrm{K}$ content increases fruit ascorbic acid and beta-carotene contents but increased synthesis through enzyme activation is a possible mechanism. In melon fruit, the enzyme lipoxygenase has been associated with cellular membrane breakdown and fruit senescence through enhanced production of free radicals, however, fruit high in beta-carotene are not affected (Lester, 1990). Ascorbic acid and beta-carotene also play similar important roles as antioxidants in humans when consumed in diets. Enhancing their accumulation in fruits, through carefully-timed, controlled $\mathrm{K}$ foliar fertilization could, therefore, enhance the human wellness potential of melons (Larson, 1997; Lester and Eischen, 1996).

To summarize, supplementing soil K supply with foliar Kapplications during fruit development and maturation improved orange-flesh muskmelon fruit quality by increasing firmness, sugar content, ascorbic acid, and beta-carotene levels. These quality improvements were obtained by implementing a simple management tool that growers can easily adopt. Future research is needed to validate these findings in typical commercial field trials (differing in $\mathrm{K}$ concentrations), under different production environments (spring vs. fall), and also to evaluate the effect of $\mathrm{K}$ source (amino acid complexed $\mathrm{K}$ vs. potassium chloride and others) on these fruit quality and health attributes of muskmelons.

\section{Literature Cited}

Bidwell, R.G.S. 1974. Soil and mineral nutrition, p. 225-248. In: R. Bidwell (ed.). Plant physiology. Macmillan, New York.

Chapagain, B.P. and Z. Wiesman. 2004. Effect of Nutri-Vant-PeaK foliar spray on plant development, yield, and fruit quality in greenhouse tomatoes. Sci. Hort. 102:177-188.

Clarkson, D.T. 1989. Ionic relations, p. 319-353. In: M. Wilkins (ed.). Advanced plant physiology. Wiley, New York.

Doman, D.C. and D.R. Geiger. 1979. Effect of exogenously supplied potassium on phloem loading in Beta vulgaris L. Plant Physiol. 64:528-533.

Engels, C. and H. Marschner. 1993. Influence of the form of nitrogen supply on root uptake and translocation of cations in the xylem exudate of maize (Zea mays L.). J. Expt. Bot. 44:1695-1701.

Fisher, J.D., D. Hausen, and T.K. Hodges. 1970. Correlation between ion fluxes and ion stimulated adenosine triphosphatase activity of plant roots. Plant Physiol. 46:812-814.

Gross, J. 1991. Carotenoids, p. 75-278. In: J. Gross (ed.). Pigments in vegetables: Chlorophylls and carotenoids. Van Nostrand Reinhold, New York.

Ho, L.C. 1988. Metabolism and compartmentation of imported sugars in sink organs in relation to sink strength. Annu. Rev. Plant Physiol. 39:355-378.

Hodges, D.W., C.F. Forney, and W.V.Wismer. 2001. Antioxidant responses in harvested leaves of two cultivars of spinach differing in senescence rates. J. Amer. Soc. Hort. Sci. 126:611-617.

Hopkins, F. 1963. Vitamin C, p. 205-210. In: J.B.S. Braverman (ed.). The biochemistry of foods. Elsevier, New York. 
Table 4. Influence of foliar applications of amino-acid-chelated potassium as a supplement to soil fertilization on edible tissue internal edible mesocarp color (Hue), soluble solids concentration, total ascorbic acid and beta-carotene contents of muskmelon ('Cruiser'). Entire plants and fruit were sprayed weekly, biweekly, or not sprayed (control) between anthesis (pollination) and fruit abscission (full-slip). Shown are data from glasshouse experiments during Spring 2003 and 2004.

\begin{tabular}{|c|c|c|c|c|c|c|c|c|}
\hline \multirow[b]{2}{*}{ Treatment } & \multicolumn{2}{|c|}{$\begin{array}{c}\text { Internal color } \\
\left(\mathrm{h}^{\mathrm{o}}\right)^{\mathrm{z}}\end{array}$} & \multicolumn{2}{|c|}{$\begin{array}{l}\text { Soluble solids } \\
\text { concn }(\%)\end{array}$} & \multicolumn{2}{|c|}{$\begin{array}{c}\text { Ascorbic acid } \\
(\mathrm{mg} / 100 \mathrm{~g} \text { fresh } \\
\mathrm{wt})\end{array}$} & \multicolumn{2}{|c|}{$\begin{array}{l}\text { Beta-carotene } \\
\left(\mu \mathrm{g} \cdot \mathrm{g}^{-1} \text { dry wt }\right)\end{array}$} \\
\hline & 2003 & 2004 & 2003 & 2004 & 2003 & 2004 & 2003 & 2004 \\
\hline Control & $70.4 b^{y}$ & $70.2 \mathrm{~b}$ & $8.0 \mathrm{~b}$ & $8.8 \mathrm{~b}$ & $21.9 \mathrm{~b}$ & $29.8 \mathrm{~b}$ & $234.4 \mathrm{c}$ & $302.6 \mathrm{c}$ \\
\hline Biweekly & $69.7 \mathrm{a}$ & $69.8 \mathrm{a}$ & $9.2 \mathrm{a}$ & $9.5 \mathrm{a}$ & $25.4 \mathrm{a}$ & $32.1 \mathrm{a}$ & $369.4 \mathrm{~b}$ & $319.3 \mathrm{~b}$ \\
\hline Weekly & $69.4 \mathrm{a}$ & $69.2 \mathrm{a}$ & $9.5 \mathrm{a}$ & $9.8 \mathrm{a}$ & $26.2 \mathrm{a}$ & $33.6 \mathrm{a}$ & $481.6 \mathrm{a}$ & $348.3 \mathrm{a}$ \\
\hline
\end{tabular}

$\mathrm{zh}^{\circ}=$ Hue angle $\left(0^{\circ}=\right.$ red-purple, $90^{\circ}=$ yellow, $180^{\circ}=$ bluish-green, $270^{\circ}=$ blue $)$.

y Means with the same letter, within a column, are not significant using Duncan's multiple range test at the $95 \%$ probability level $(n=10)$.

Table 5. Effects of foliar applications of amino-acid-chelated potassium as a supplement to soil fertilization on edible tissue fructose, glucose, sucrose and total sugar concentrations of muskmelon ('Cruiser'). Entire plants and fruit were sprayed weekly, biweekly or not sprayed (control) between anthesis (pollination) and fruit abscission (full-slip). Shown are data from glasshouse experiments during Spring 2003 and 2004.

\begin{tabular}{|c|c|c|c|c|c|c|c|c|}
\hline \multirow[b]{2}{*}{ Treatment } & \multicolumn{2}{|c|}{$\begin{array}{c}\text { Fructose } \\
\text { (mg.g }{ }^{-1} \text { dry wt) }\end{array}$} & \multicolumn{2}{|c|}{$\begin{array}{c}\text { Glucose } \\
\text { (mg } \cdot \mathrm{g}^{-1} \text { dry wt) }\end{array}$} & \multicolumn{2}{|c|}{$\begin{array}{l}\text { Sucrose } \\
\left(\mathrm{mg} \cdot \mathrm{g}^{-1} \text { dry wt) }\right.\end{array}$} & \multicolumn{2}{|c|}{$\begin{array}{l}\text { Total sugars } \\
\left(\mathrm{mg} \cdot \mathrm{g}^{-1} \text { dry wt) }\right.\end{array}$} \\
\hline & 2003 & 2004 & 2003 & 2004 & 2003 & 2004 & 2003 & 2004 \\
\hline Control & $128 b^{z}$ & $164 \mathrm{c}$ & $82 \mathrm{a}$ & 113 & $28 \mathrm{C}$ & $317 \mathrm{c}$ & 499 & $594 \mathrm{c}$ \\
\hline Biweekly & $154 \mathrm{a}$ & $194 \mathrm{~b}$ & $87 \mathrm{a}$ & $137 \mathrm{~b}$ & $293 \mathrm{a}$ & $385 \mathrm{~b}$ & $434 \mathrm{~b}$ & $716 \mathrm{~b}$ \\
\hline Weekly & $158 \mathrm{a}$ & $255 \mathrm{a}$ & $89 a$ & $169 \mathrm{a}$ & $302 \mathrm{a}$ & $426 \mathrm{a}$ & $549 \mathrm{a}$ & $850 \mathrm{a}$ \\
\hline
\end{tabular}

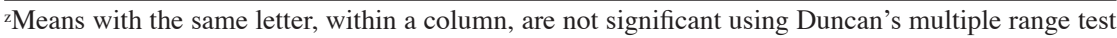
at the $95 \%$ probability level $(n=10)$.

Koch, T.C. and I.L. Goldman. 2004. Aone-pass semi-quantitative method for extraction and analysis of carotenoids and tocopherols in carrots. HortScience 39:1260-1261.

Larson, H.R. 1997. Vitamin C: Your ultimate health insurance. Intl. J. Alternative Complementary Med. 15:208-220.

Lester, G. and J.R. Dunlap. 1985. Physiological changes during development and ripening of 'Perlita' muskmelon fruits. Scientia Hort. 26:323-331.

Lester, G.E. 1990. Lipoxygenase activity of hypodermal- and middlemesocarp tissues from netted muskmelon fruit during maturation and storage. J. Amer. Soc. Hort. Sci. 115:612-615.

Lester, G.E. and F. Eischen. 1996. Beta-carotene content of postharvest orange-flesh muskmelon fruit: Effect of cultivar, growing location and fruit size. Plant Foods Human Nutr. 49:191-197. Lester, G.E. and M.A. Grusak. 1999. Postharvest application of calcium and magnesium to honeydew and netted muskmelons: Effects on tissue ion concentrations, quality and senescence. J.Amer. Soc. Hort. Sci. 124:545-552.

Lester, G.E., L. Saucedo Arias, and M. Gomez-Lim. 2001. Muskmelon fruit soluble acid invertase and sucrose phosphate sunthase activity and polypeptide profiles during growth and maturation. J. Amer. Soc. Hort. Sci. 126:33-36.

Lin, D., D. Huang, and S. Wang. 2004. Effects of potassium levels on fruit quality of muskmelon in soilless medium culture. Scientia Hort. 102:53-60.

Marschner, H. 1995. Functions of mineral nutrients: macronutirents, p. 299-312. In: H. Marschner (ed.). Mineral nutrition of higher plants. $2^{\text {nd }} e d$. Academic, New York.

Mengel, K. and E.A. Kirkby. 1980. Potassium in crop production. Adv. Agron. 33:59-110.

Peel, A.J. and S. Rogers. 1982. Stimulation of sugar loading into sieve elements of willow by potassium and sodium salts. Planta 154:94-96.

Peoples, T.R. and D.W. Koch. 1979. Role of potassium in carbon dioxide assimilation in Medicago sativa L. Plant Physiol. 63:878-881.

Pettigrew, W.T. 1999. Potassium deficiency increases specific leaf weights and leaf glucose levels in fieldgrown cotton. Agron. J. 91:962-968.

Shallenberger, R.S. 1980. Predicting sweetness from chemical structure and knowledge of chemoreception. Food Tech. 34:65-67.

Swietlik, D. and M. Faust. 1984. Foliar nutrition of fruit crops. Hort. Rev. 6:287-356.

Tao, Q.N., P. Fang, L.H. Guan, and M.Z. Chen. 1990. Effects of N, P, K on yield and flavour components of watermelon. China Watermelon Melon 3:22-26.

Tester, M. and M.R. Blatt. 1989. Direct measurement of $\mathrm{K}^{+}$channels in thylakoid membranes by incorporation of vesicles planar lipid bilayers. Plant Physiol. 91:249-252.

Terry, N and A. Ulrich. 1973. Effects of potassium deficiency on the photosynthesis and respiration of leaves of sugar beet. Plant Physiol. 51:783-786

Wyn Jones, R.G., C.J. Brady, and J. Speirs. 1979. Ionic and osmotic relations in plant cells, p. 63-103. In: D.L. Laidman and R.G. Wyn Jones (eds.). Recent advances in the biochemistry of cereals. Academic, London. 